\title{
Prediction of surgical outcomes of extended thymectomy for patients with myasthenia gravis: Where are we now?
}

Ting Ye, MD, PhD, and Haiquan Chen, MD, PhD

\author{
From the Department of Thoracic Surgery, Shanghai Cancer Center, Fudan University, Shanghai, China \\ Disclosures: Authors have nothing to disclose with regard to commercial support. \\ Received for publication Dec 21, 2017; revisions received Jan 10, 2018; accepted for publication Jan 26, 2018 ; \\ available ahead of print March 16, 2018. \\ Address for reprints: Haiquan Chen, MD, PhD, 270 Dong'an Rd, Shanghai, China 200032 (E-mail: hqchen1@ \\ yahoo.com) \\ J Thorac Cardiovasc Surg 2018;155:2745 \\ 0022-5223/\$36.00 \\ Copyright (C) 2018 by The American Association for Thoracic Surgery \\ https://doi.org/10.1016/j.jtcvs.2018.01.057
}

Extended thymectomy is an important treatment for patients with myasthenia gravis (MG). Not all patients benefit from resection, however, and the remission rate for nonthymomatous MG after surgery ranges from $38 \%$ to $72 \%$. Accordingly, finding reliable predictors of surgical outcomes is necessary. Some studies have claimed that several factors including age, Osserman stage of MG, and pathologic features of the thymus tissue could predict surgical outcomes. Presence of thymic hyperplasia, absence of thymoma, and absence of ectopic thymus are especially associated with better surgical outcomes. In actuality, however, surgical indications for MG remain controversial. On the basis of pathogenesis, removal of thymic tissue in which anti-acetylcholine receptor antibody (AChRAb) is produced by thymocytes or lymphocytes could decrease serum AChRAb level, thus theoretically improving the outcomes for patients with AChRAb-positive MG.

In their study in this issue of the Journal, Takahagi and colleagues ${ }^{1}$ have tested the hypothesis that the anterior mediastinal tissue volume assessed by preoperative 3-dimensional computed tomography $\left(\mathrm{V}_{30}\right)$ could predict serum AChRAb levels. The idea seems interesting and logical. They performed a well-designed retrospective study and showed us the positive results (1) that the volume of anterior nonadipose mediastinal tissue correlated with preoperative AChRAb levels and inversely correlated with postoperative to preoperative AChRAb ratios and (2) that the histologic volume ratio of cells in the resected tissue was strongly correlated with the $\mathrm{V}_{30} / \mathrm{V}_{\mathrm{AM}}$ (the total volume of the anterior mediastinum including anterior mediastinal and pericardial adipose tissue, but excluding the volume of thymoma is defined as VAM) ratio. They concluded that quantification of the anterior mediastinal tissue volume with 3-dimensional CT may help in making a surgical plan for MG.

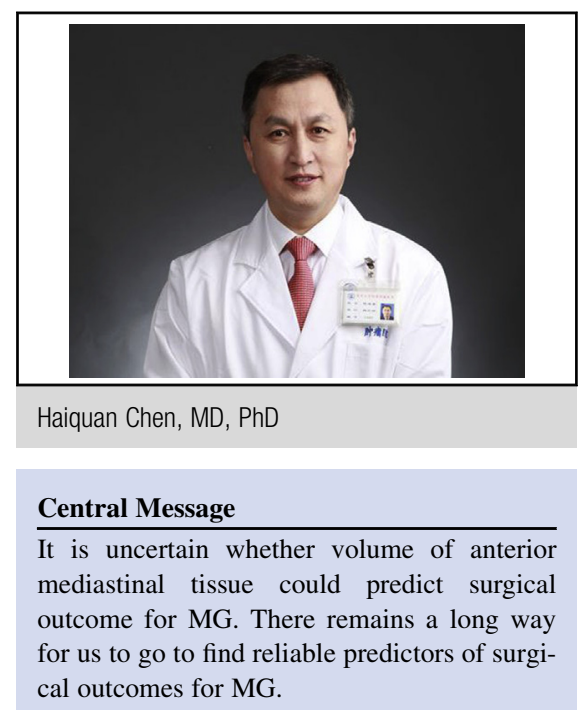

See Article page 2738 .

The study of Takahagi and colleagues ${ }^{1}$ provides some insights into further selection of surgical candidates among patients with MG. On the other hand, the main limitation of this study is its lack of clinical significance. We do not have enough evidence whether serum AChRAb level is associated with the severity of $\mathrm{MG}$, or that the change in AChRAb level after surgery could predict clinical improvement of MG. Although this study did show a positive correlation between $\mathrm{V}_{30}$ and preoperative $\mathrm{AChRAb}$ level and an inverse correlation with the postoperative to preoperative $\mathrm{AChRAb}$ ratio, it is still uncertain whether volume of anterior mediastinal tissue could predict the surgical outcome for patients with MG. There thus remains a long way for us to go to find reliable predictors of surgical outcomes for patients with MG. Further prospective studies are needed for this issue.

\section{Reference}

1. Takahagi A, Omasa M, Chen-Yoshikawa TF, Hamaji M, Yoshizawa A, Sozu T, et al. Anterior mediastinal tissue volume is correlated with antiacetylcholine receptor antibody level in myasthenia gravis. J Thorac Cardiovasc Surg. 2018; $155: 2738-44$ 